\title{
Efficiency of Different Moringa oleifera (Lam.) Varieties as Natural Coagulants for Urban Wastewater Treatment
}

\author{
Nidhal Marzougui ${ }^{1, *(\mathbb{D}}$, Ferdaous Guasmi ${ }^{2}$, Sondes Dhouioui ${ }^{1}$, Mohamed Bouhlel ${ }^{1}$, Mohamed Hachicha ${ }^{1}$, \\ Ronny Berndtsson ${ }^{3, *(1)}$ and Noomene Sleimi ${ }^{4}(\mathbb{C}$ \\ 1 LR Valorisation des Eaux Non Conventionnelles (LR 16INRGREF02), Institut National de Recherches en \\ Génie Rural, Eaux et Forets, Université de Cartahge, 17 Rue Hédi Karray, BP No. 10, Ariana 2080, Tunisia; \\ dhouiouisondes@gmail.com (S.D.); bouhlelmohamed13@gmail.com (M.B.); \\ hachicha.mohamed@iresa.agrinet.tn (M.H.) \\ 2 Laboratoire d'Aridoculture et Cultures Oasiennes, Institut des Régions Arides, Université de Gabès, \\ Route ElJorf, Medenine 4119, Tunisia; guasmifer@yahoo.fr \\ 3 Centre for Advanced Middle Eastern Studies \& Division of Water Resources Engineering, Lund University, \\ 22100 Lund, Sweden \\ 4 LR-RME Resources, Materials and Ecosystems, Faculty of Sciences of Bizerte, University of Carthage, \\ Jarzouna, Bizerte 7021, Tunisia; noomene.sleimi@gmail.com \\ * Correspondence: marzouguinidhal@gmail.com (N.M.); ronny.berndtsson@tvrl.lth.se (R.B.)
}

Citation: Marzougui, N.; Guasmi, F.; Dhouioui, S.; Bouhlel, M.; Hachicha, M.; Berndtsson, R.; Sleimi, N. Efficiency of Different Moringa oleifera (Lam.) Varieties as Natural Coagulants for Urban Wastewater Treatment. Sustainability 2021, 13, 13500. https://doi.org/10.3390/ su132313500

Academic Editors: Farooq Sher, Gyan Chhipi Shrestha, Bingyi Kang, Ianis Delpla and Nicolas Beauchamp

Received: 27 October 2021

Accepted: 1 December 2021

Published: 6 December 2021

Publisher's Note: MDPI stays neutral with regard to jurisdictional claims in published maps and institutional affiliations.

Copyright: (c) 2021 by the authors. Licensee MDPI, Basel, Switzerland. This article is an open access article distributed under the terms and conditions of the Creative Commons Attribution (CC BY) license (https:/ / creativecommons.org/licenses/by/ $4.0 /)$.

\begin{abstract}
There is a great need to find cheaper but still efficient treatment methods for wastewater. This study aimed to test the purifying performance of three different Moringa oleifera varieties that were cultivated in Tunisia on raw (RUW) and secondary treated urban wastewater (TUW). The seeds of the Mornag, Egyptian, and Indian varieties were powdered, added to the water (at concentrations of $0,50,100$, and $150 \mathrm{mg} \cdot \mathrm{L}^{-1}$ ), and stirred for $45 \mathrm{~min}$ at $120 \mathrm{rpm}$, and then left to settle for two hours. A physicochemical characterization of the wastewater was carried out before and after treatment. The investigated treatments decontaminated both types of urban wastewater. The best treatments were obtained with the Egyptian variety (at $150 \mathrm{mg} \cdot \mathrm{L}^{-1}$ ), which excelled at the reduction of EC, TSS, $\mathrm{BOD}_{5}, \mathrm{Cl}, \mathrm{SO}_{4}, \mathrm{Ca}, \mathrm{Na}, \mathrm{Cd}$, and $\mathrm{Fe}$ in $\mathrm{RUW}$ and $\mathrm{BOD}_{5}, \mathrm{EC}, \mathrm{Na}, \mathrm{Mg}, \mathrm{Cl}$, and $\mathrm{Cd}$ in TUW. High amounts of TKN was found in both types of Moringa-treated wastewater, meaning that it could be used in agricultural irrigation, leading to less use of chemical nitrogen fertilizers and thus improving sustainability for crops, soils, animals, and humans. The Egyptian Moringa variety constitutes a cost-effective and environmentally friendly adsorbent that can be used as a replacement for more expensive treatment technologies.
\end{abstract}

Keywords: coagulation; Moringa oleifera; raw urban wastewater; removal efficiency; treated urban wastewater

\section{Introduction}

The increasing use of freshwater in agricultural, industrial, and human consumption threatens freshwater reserves across the globe, causing significant shortages. In addition, since the 1990s, the problem of water pollution has worsened in almost all rivers in Africa, Latin America, and Asia [1]. The deterioration of water quality is expected to intensify in the coming decades [2]. It is estimated that $80 \%$ of all domestic and industrial wastewater worldwide is discharged into the environment without any prior treatment, resulting in increasing overall water quality deterioration and causing harmful effects on human health, ecosystems, and sustainable development [3]. Wastewater discharge is increasing continuously due to industrial development and the rise in the living standards of the world's population. The self-purification capacities have been exceeded, which forces researchers to develop new techniques to purify these effluents [4].

Wastewater purification constitutes a set of techniques that are used to treat wastewater either for reuse or recycling in the natural environment. Conventional wastewater 
treatment processes (chemical precipitation, adsorption on activated carbon, ion exchange, evaporation, and membrane processes) entail major difficulties in removing metallic elements [5]. They are not sustainable due to a large carbon footprint and high energy demand. These processes generate a significant amount of greenhouse gases annually that can vary between 61 and $161 \mathrm{~kg}$ of carbon dioxide equivalent per population equivalent $\left(\mathrm{CO}_{2} \mathrm{eq} / \mathrm{PE}\right)$, depending on the treatment process. Their specific annual energy consumption can vary from 15 to $86 \mathrm{kWh} / \mathrm{PE}$ [6]. Thus, current treatment methods are expensive and insufficient to meet the present regulatory limits [7]. As a result, new approaches for sustainable wastewater treatment need to be developed that integrate ecological and economical concerns. This can be achieved by coupling the mineralization of organic pollutants that generate $\mathrm{CO}_{2}$ with photosynthesis (i.e., reducing $\mathrm{CO}_{2}$ emissions by utilizing biological materials, such as microorganisms and plants) [8]. New techniques for removing wastewater pollutants, such as metallic elements, are being continuously developed with increased performance and lower costs [9]. Moreover, treatment processes that are environmentally friendly and inexpensive, and which reduce by-products, improve biodegradability, and consume less energy, are advantageous [10]. Some of these treatments essentially consist of using plants to absorb the cations that are contained in the effluent, and thus plant materials act as extractors of macro- and micro-nutrients within effluents [11].

The species Moringa oleifera Lam. (M. oleifera) has been newly introduced in Tunisia and in the Middle East and North Africa (MENA). Tunisia is suffering from severe water shortages, and thus has adopted the treated wastewater reuse strategy to minimize pressure on conventional water resources [12]. The seeds of this tropical multi-purpose tree contain water-soluble, positively charged proteins, which can act as an effective coagulant to target various aspects of the treatment of conventional water and wastewater, such as turbidity, alkalinity, total dissolved solids, and hardness $[13,14]$. Research has still not been conducted on the potential for the M. oleifera seed to treat wastewater in Tunisia. Globally, however, M. oleifera has already been employed as a natural coagulant to purify contaminated effluents [10]. However, its biosorption behavior as it relates to the elimination of heavy metals, toxic organic compounds (hydrocarbon, nitrogenous, phosphate materials, etc.), and microorganisms from wastewater needs to be further studied [14]. Furthermore, the efficiency of treatment needs to be investigated for different climates and different types of wastewaters.

In view of the above, the objective of this study was to test the purifying performance of the seeds of three different M. oleifera varieties that are cultivated in Tunisia on raw and secondary treated urban wastewater. Many countries in the MENA suffer from water shortages, which are coupled with a lack of energy and chemicals for the treatment of wastewater. Thus, developing new, inexpensive treatment methods that can be used in a hot, dry climate is of ultimate importance. In this sense, the study is of high concern, novel, and can potentially expand the market for this type of treatment product in the MENA.

\section{Materials and Methods}

\subsection{Plant Materials and Wastewater Sampling}

The seeds of the three M. oleifera varieties that were used in this study were collected from Tunisian farmers in 2017 by the Research Laboratory Valorization of NonConventional Water team and retained in hermetically sealed boxes under ambient laboratory conditions with temperatures varying from 20 to $28^{\circ} \mathrm{C}$. Seed sample authentication was performed according to the OECD (Organisation for Economic Cooperation and Development) seed scheme procedure for verifying the M. oleifera varieties' progress at different stages in the seed production process. This was based on the examination of farmers' control plots through laboratory tests on the M. oleifera seeds and seedling samples that were taken from various lots, and through several field inspections of the M. oleifera crops as they grew. Figure 1 and Table 1 show the seed morphology and characteristics of the three identified varieties, which are named the Mornag, Egyptian, and Indian varieties. 


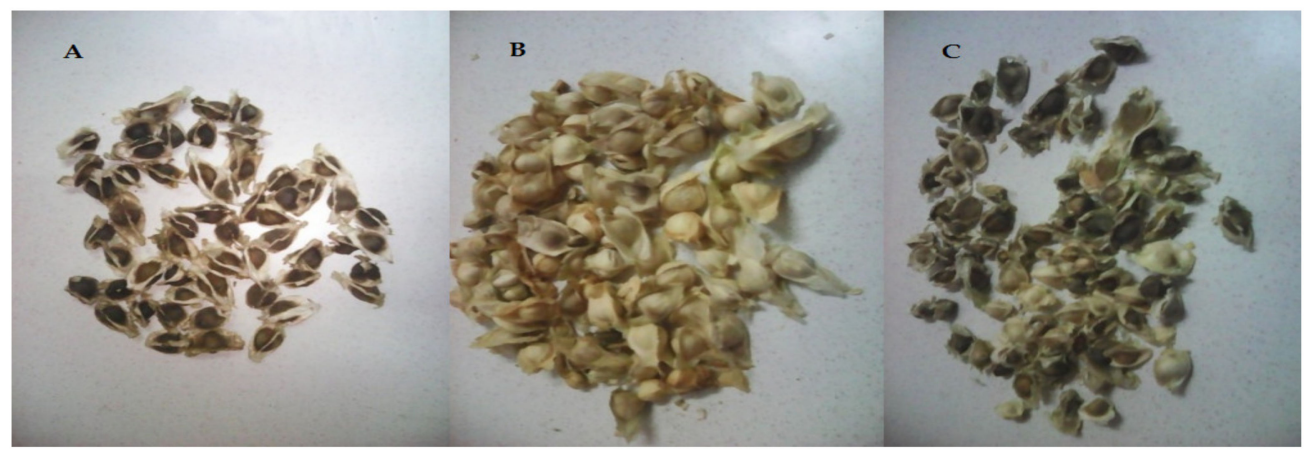

Figure 1. Seeds of the studied varieties of Moringa oleifera Lam: (A) Mornag variety; (B) Egyptian variety; and (C) Indian variety.

Table 1. Qualitative and quantitaive parameters for characterization of the seeds of the studied Moringa oleifera varieties $(n=3)$.

\begin{tabular}{cccc}
\hline Parameter & Mornag & Egyptian & Indian \\
\hline Seed color & Dark brown & Light brown & Dark brown \\
Wing color & White & Light brown & Light brown \\
100 seeds weight $(\mathrm{g})$ & $33.68 \pm 0.2$ & $31.12 \pm 0.1$ & $38.25 \pm 0.3$ \\
Seed length $(\mathrm{mm})$ & $1.05 \pm 0.1$ & $0.92 \pm 0.2$ & $1.29 \pm 0.1$ \\
Seed diameter $(\mathrm{mm})$ & $1.01 \pm 0.2$ & $0.89 \pm 0.1$ & $1.06 \pm 0.1$ \\
Wing length $(\mathrm{cm})$ & $3.23 \pm 0.1$ & $2.98 \pm 0.1$ & $3.64 \pm 0.2$ \\
Seed-wing diameter $(\mathrm{cm})$ & $1.95 \pm 0.1$ & $1.58 \pm 0.09$ & $2.02 \pm 0.08$ \\
\hline
\end{tabular}

\subsection{Wastewater Sampling}

A total of 112 out of 122 treatment plants treat wastewater that is of urban origins in Tunisia [15]. The raw (RUW) and secondary treated urban wastewater (TUW) that was used in this study was collected in November 2017 in clean polyethylene bottles, according to a representative sampling regime that comprised $24 \mathrm{~h}$ average samples being taken from the entrance and the exit of the secondary treatment section of the wastewater treatment plant (WWTP) of Grombalia City, an agricultural town that is located in the northeast of Tunisia (Figure 2). This WWTP has recently undergone total rehabilitation and extension after having exceeded 15 years of service [15]. Its main characteristics, as well as its treatment process, are shown in Figure 2.

\subsection{Seed Processing, Wastewater Treatment, and Analyses}

The coat and wings of the Moringa oleifera seeds were removed manually. The seeds were washed with $95 \%$ ethanol, dried, ground until a fine powder was obtained, and sieved through a $44 \mathrm{~mm}$ sieve [16]. Each wastewater quality sample was treated with increasing concentrations of the Moringa seed coagulant (50, 100, and $150 \mathrm{mg} \cdot \mathrm{L}^{-1}$ ), as described by Mangale Sapana et al. [17]. The solutions were kept on the agitator for $45 \mathrm{~min}$ at 110-120 rpm and then put to rest for $2 \mathrm{~h}$. After sedimentation, the obtained supernatant constituted the purified wastewater [17]. The physicochemical characterization of the wastewater, before and after treatment, was based on the parameters given in Table 2 for the NT 106.02 and NT 106.03 standards, which relate to the discharge of treated wastewater to the environment and its reuse for agricultural purposes, respectively $[18,19]$. 
Main operational characteristics of Grombalia WWTP:

-Capacity: 35111 Equivalent inhabitants

-Design rate flow: $3082 \mathrm{~m}^{3} /$ day

-Organic load at the entrance: $1582 \mathrm{KgDBO}_{5} /$ day

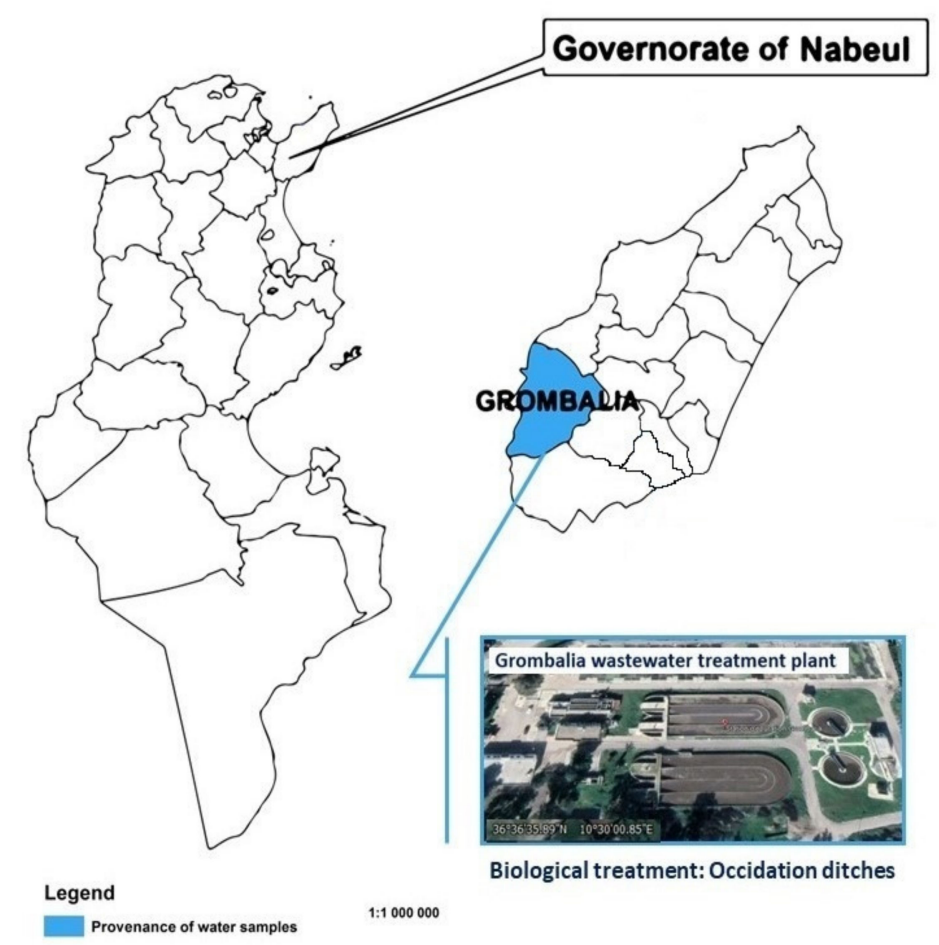

Figure 2. Location of wastewater treatment sampling in Tunisia (source: ArcGIS 10.3).

Table 2. Studied parameters and analysis methods.

\begin{tabular}{|c|c|c|c|}
\hline Parameter & Method of Analysis & Unit & Source \\
\hline Conductivity (EC) & $\begin{array}{l}\text { WTW LF330 conductometer } \\
\text { (Germany) }\end{array}$ & $\left(\mathrm{mS} \cdot \mathrm{cm}^{-1}\right)$ & \\
\hline Mean hydrogen ion concentration $(\mathrm{pH})$ & Adwa 1000 pH meter (Romania) & - & \\
\hline Chemical oxygen demand (COD) & Method by oxidation with $\mathrm{KMnO}_{4}$ & $\left(\mathrm{mg} \mathrm{O}_{2} \cdot \mathrm{L}^{-1}\right)$ & {$[20]$} \\
\hline Five-day biochemical oxygen demand $\left(\mathrm{BOD}_{5}\right)$ & Instrumental method & $\left(\mathrm{mg} \mathrm{O}_{2} \cdot \mathrm{L}^{-1}\right)$ & [20] \\
\hline Total suspended solids (TSS) & Filtration on filter paper & & [21] \\
\hline Chloride $(\mathrm{Cl})$ & Mohr method & $\left(\mathrm{mg} \cdot \mathrm{L}^{-1}\right)$ & [22] \\
\hline Sodium $(\mathrm{Na})$, potassium $(\mathrm{K})$ & $\begin{array}{c}\text { Spectrometric method with flame photometer } \\
\text { Jenway PFP7 (U.K.) }\end{array}$ & $\left(\mathrm{mg} \cdot \mathrm{L}^{-1}\right)$ & [23] \\
\hline Calcium (Ca), magnesium (Mg) & $\begin{array}{l}\text { Complexometric EDTA (Chem-Lab) } \\
\text { titration with basic medium }\end{array}$ & $\left(\mathrm{mg} \cdot \mathrm{L}^{-1}\right)$ & [24] \\
\hline Sulfate $\left(\mathrm{SO}_{4}\right)$ & Manual spectrometric method & $\left(\mathrm{mg} \cdot \mathrm{L}^{-1}\right)$ & [23] \\
\hline Bicarbonate $\left(\mathrm{HCO}_{3}\right)$ & Volumetric titration & $\left(\mathrm{mg} \cdot \mathrm{L}^{-1}\right)$ & [23] \\
\hline Total Kjeldahl nitrogen (TKN) & Manual spectrometric method & $\left(\mathrm{mg} \cdot \mathrm{L}^{-1}\right)$ & [25] \\
\hline $\begin{array}{l}\text { Metal trace elements }(\mathrm{MTE}) \text { : cadmium }(\mathrm{Cd}) \text {, } \\
\text { lead }(\mathrm{Pb}) \text {, nickel }(\mathrm{Ni}) \text {, zinc }(\mathrm{Zn}) \text {, iron }(\mathrm{Fe})\end{array}$ & $\begin{array}{l}\text { Atomic absorption spectroscopy with } \\
\text { PerkinElmer PinAAcle } 900 \text { T, USA. }\end{array}$ & $\left(\mathrm{mg} \cdot \mathrm{L}^{-1}\right)$ & [26] \\
\hline
\end{tabular}

\subsection{Statistical Analyses}

Statistical analyses were performed for three independent factors (wastewater quality, Moringa variety, and coagulant concentration), which were used to explain variations in the dependent quantitative variables: chemical oxygen demand (COD), five-day biochemical oxygen demand $\left(\mathrm{BOD}_{5}\right)$, total suspended solids (TSS), electrical conductivity (EC), mean hydrogen ion concentration $(\mathrm{pH})$, and concentrations of chloride $(\mathrm{Cl})$, bicarbonate $\left(\mathrm{HCO}_{3}\right)$, sulfate $\left(\mathrm{SO}_{4}\right)$, calcium $(\mathrm{Ca})$, magnesium $(\mathrm{Mg})$, potassium $(\mathrm{K})$, sodium $(\mathrm{Na})$, total Kjeldahl 
nitrogen $(\mathrm{TKN})$, cadmium $(\mathrm{Cd})$, zinc $(\mathrm{Zn})$, iron $(\mathrm{Fe})$, lead $(\mathrm{Pb})$, and nickel $(\mathrm{Ni})$. The normality of the quantitative variables was assessed using the Shapiro-Wilk test. An analysis of variance (ANOVA) was performed using SPSS software (IBM SPSS statistics, version 20), and this was complemented by a Duncan's test of the Moringa varieties and coagulant concentration groups to compare their means using a pairwise comparison. Values of $p<0.05$ were considered to be statistically significant. Principal component analysis (PCA) was performed using XLSTAT software (Adinosoft, version 2014.5.03), based on the removal efficiency $(H \%)$ of the physicochemical parameters of the wastewater that was treated by the $M$. oleifera coagulant. The $H$ value was calculated using the following formula: $\%(H)=\left[\frac{C i-C f}{C i}\right] \times 100$; where $C i$ and $C f$ are the initial and final concentrations of corresponding parameters [27].

\section{Results and Discussion}

\subsection{Urban Wastewater Treatment \\ 3.1.1. $\mathrm{pH}$ Change}

The $\mathrm{pH}$ greatly affects the coagulation conditions. An optimal $\mathrm{pH}$ leads to the best coagulation when the solubility of the coagulant is minimal, which gives better precipitation [28]. At this optimum $\mathrm{pH}$, Hendrawati et al., stated that the amino acids of the coagulating peptide, such as that of M. oleifera (named MO 2.1) [27], ionize to make carboxylate ions and protons, while the proton charge attracts electrons to produce a neutral group and then form flocs [29]. For the Moringa's non-protein organic components, the coagulation mechanism was described by Villaseñor-Basulto et al., as a cross-linked structure with a network form in the manner that has been proposed for sweep coagulation processes [10]. The results here showed that the $\mathrm{pH}$ values before the Moringa treatment were 7.2 for raw urban wastewater (RUW) and 7.7 for treated urban wastewater (TUW) (Table 3). The value was ideal for coagulation in the RUW but less ideal for coagulation in the TUW, according to Naceradska et al. [30], who found that the optimal $\mathrm{pH}$ range for natural organic substance coagulation is about 4-7.5. The treatment slightly increased the $\mathrm{pH}$ of the RUW and slightly decreased that of the TUW (Table 3). The $\mathrm{pH}$ was not altered significantly by the three factors that we focused on, however $(p>0.05$; Table 4$)$. In view of the above, the increase in the $\mathrm{pH}$ that followed the treatment may have resulted in the release of carboxylate groups, which shifted the solution's $\mathrm{pH}$ to alkaline, allowing for colloid destabilization, according to the mechanism proposed by Hendrawati et al. [29]. However, other authors have previously suggested that this process is caused by the release of hydroxyl groups [31,32]. Thus, it is still under debate exactly what the process is that is influencing these results.

Table 3 shows that the $\mathrm{pH}$ of the two types of urban wastewater that we studied falls within the recommended $\mathrm{pH}$ range (6.5-8.5) for the agricultural reuse of TUW, according to Tunisian standards, even after treatment with the Moringa coagulant, meaning that the Moringa coagulant appears to be suitable for treating RUW for agricultural reuse purposes. No additional step was required to adjust the $\mathrm{pH}$ value after the treatment. 
Table 3. Physicochemical characterization of raw and treated urban wastewater before and after treatment with three varieties of Moringa oleifera.

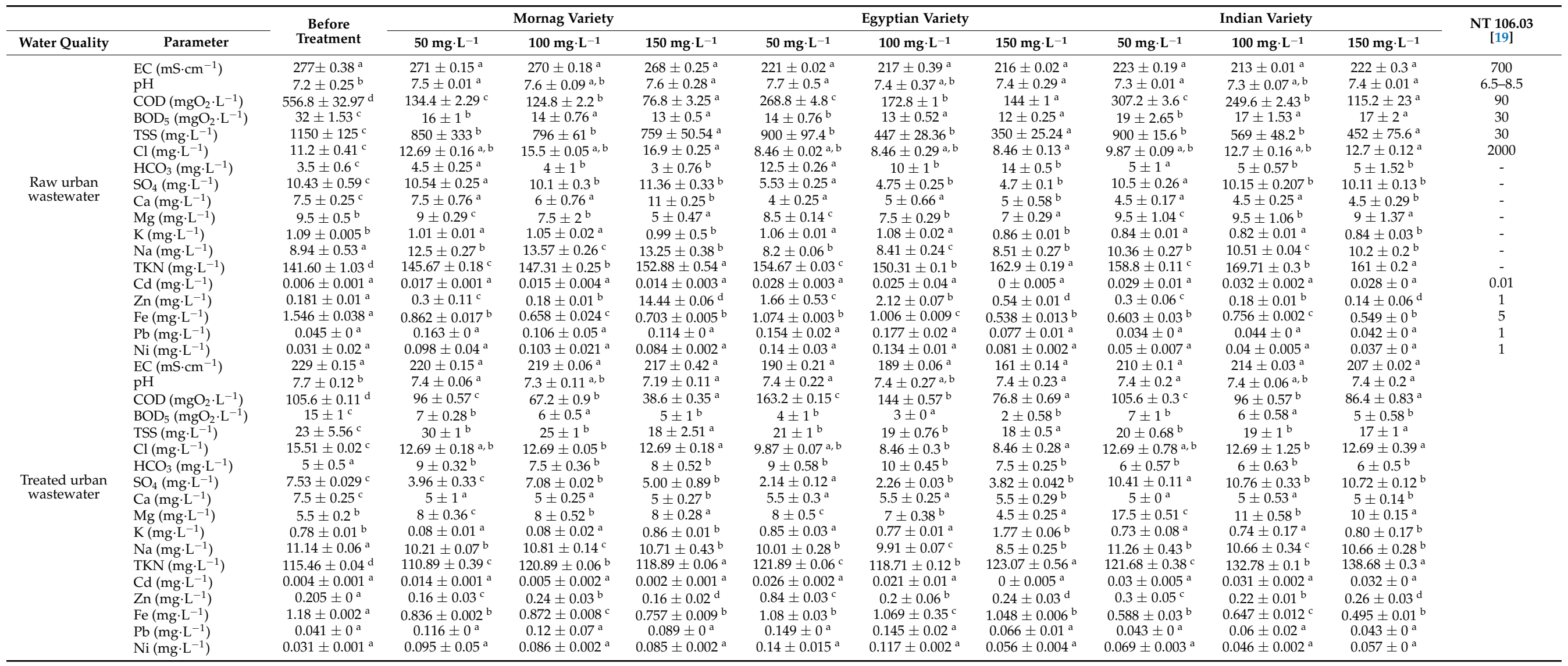

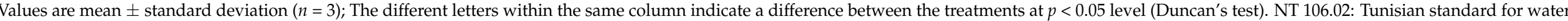

discharge to the environment. NT 106.02: Tunisian standard for wastewater reuse in agriculture. 
Table 4. Interactive effects of treatment with Moringa oleifera varieties as coagulant used at different concentrations with tow different urban wastewater qualities: Raw and secondary treated.

\begin{tabular}{|c|c|c|c|c|c|c|c|}
\hline \multirow[b]{2}{*}{ Parameters } & \multicolumn{7}{|c|}{ Interactions } \\
\hline & $\begin{array}{c}\text { Wastewater } \\
\text { Quality }\end{array}$ & Variety & $\begin{array}{c}\text { Coagulant } \\
\text { Concentration }\end{array}$ & $\begin{array}{l}\text { Quality } \\
\times \text { Variety }\end{array}$ & $\begin{array}{c}\text { Quality } \times \\
\text { Concentration }\end{array}$ & $\begin{array}{c}\text { Variety } \times \\
\text { Concentration }\end{array}$ & $\begin{array}{c}\text { Quality } \times \\
\text { Variety } \times \\
\text { Concentration }\end{array}$ \\
\hline $\mathrm{EC}$ & * & * & NS & NS & NS & NS & NS \\
\hline $\mathrm{pH}$ & NS & NS & NS & NS & NS & NS & NS \\
\hline COD & $*$ & * & $*$ & $*$ & $*$ & $*$ & $*$ \\
\hline $\mathrm{BOD}_{5}$ & * & * & * & * & NS & NS & NS \\
\hline TSS & * & * & * & * & $*$ & $*$ & $*$ \\
\hline TKN & * & * & * & * & * & * & * \\
\hline $\mathrm{K}$ & * & * & * & * & * & NS & * \\
\hline $\mathrm{Na}$ & * & * & NS & * & * & $*$ & * \\
\hline $\mathrm{Cl}$ & * & * & NS & * & $*$ & $*$ & * \\
\hline $\mathrm{HCO}_{3}$ & * & * & NS & * & NS & NS & * \\
\hline $\mathrm{SO}_{4}$ & * & * & $*$ & * & $*$ & $*$ & * \\
\hline $\mathrm{Ca}$ & $*$ & * & * & * & * & $*$ & * \\
\hline $\mathrm{Mg}$ & NS & * & * & * & * & NS & * \\
\hline $\mathrm{Cd}$ & - & - & - & - & - & - & - \\
\hline $\mathrm{Zn}$ & * & * & * & $*$ & $*$ & * & * \\
\hline $\mathrm{Fe}$ & NS & * & * & NS & NS & * & * \\
\hline
\end{tabular}

NS: not significant at $p<0.05 ; *$ significant at $p<0.05$.

\subsubsection{EC Change}

EC reflects the degree of the water's overall mineralization [33]. Treatment with the Moringa coagulant reduced the EC of both the RUW and the TUW, which were initially compliant with the standards anyway. Villaseñor-Basulto et al., also confirmed this when they recorded an EC removal rate of $17 \%$ following their treatment of municipal effluents using M. oleifera seeds [10]. The reduction in EC likely occurred as a result of the addition of the Moringa coagulant, which led to the dispersion of minerals and inorganic compounds, and this was followed by precipitation and the formation of flocs that were then separated from the solution [29]. The variation in EC was significant according to the wastewater quality and Moringa variety factors, but it did not depend significantly upon the coagulant concentrations (Table 4). The Egyptian variety was the most effective at reducing EC for both types of urban wastewater, and its best removal efficiency $(29.7 \%)$ was recorded with the TUW at $150 \mathrm{mg} \cdot \mathrm{L}^{-1}$ of Moringa coagulant (Table 3).

\subsection{3. $\mathrm{COD}$ and $\mathrm{BOD}_{5}$ Removal}

In urban wastewater, the COD levels are related to industrial pollution and the BOD levels are directly linked with domestic human waste. The bacteria present in wastewater feed on the complex organic matter that pollutes the water, breaking them down into simpler compounds, such as carbon dioxide and water, a process ultimately leading to bacteria multiplication [34]. The high levels of COD $\left(556.8 \mathrm{mgO}_{2} \cdot \mathrm{L}^{-1}\right)$ and $\mathrm{BOD}_{5}\left(32 \mathrm{mgO}_{2} \cdot \mathrm{L}^{-1}\right)$ in the control RUW show that the samples were highly polluted by pathogenic bacteria, suggesting that these bacteria used the dissolved oxygen for organic matter degradation. The seeds of the three Moringa varieties were all efficient at removing COD in both types of urban wastewater. Statistical analyses revealed a significant effect on the COD content caused by the "wastewater quality", "coagulant concentration", and "variety used" factors taken separately, while their combined effect was also significant $(p<0.05$; Table 4). Treatment with the Moringa seeds decreased the COD in the RUW compared to the control, and this effect did depend on the coagulant dose. However, most of the COD values that we obtained still exceed the limit values fixed in the Tunisian NT 106.03 standards that govern agricultural reuse (Table 3). Only the Mornag variety 
treatment at the dose of $150 \mathrm{mg} \cdot \mathrm{L}^{-1}$ resulted in a COD content of the RUW in accordance with the standards, given its $86.2 \%$ removal efficiency. Similarly, for the TUW, an increase in the coagulant dosage decreased the COD. The Mornag variety coagulant was the most effective at treating the TUW. It resulted in COD values that comply with the standards when using an added dose of $100 \mathrm{mg} \cdot \mathrm{L}^{-1}$ (Table 3). However, the highest COD removal efficiency $(63.4 \%)$ was obtained with the coagulant dose of $150 \mathrm{mg} \cdot \mathrm{L}^{-1}$. In addition, the Egyptian and Indian varieties, at the dose of $150 \mathrm{mg} \cdot \mathrm{L}^{-1}$, removed enough COD from the TUW for it to comply with the Tunisian standards that govern agricultural reuse. Nonfodji et al., found that the removal percentage of COD from hospital wastewater increased when the Moringa coagulant dosage was increased. They also showed that preparing the $M$. oleifera seeds with a protein-polyaluminum chloride composite coagulant improves the coagulation process, leading to better COD removal [35]. Adsorption and charge neutralization are the most likely mechanisms by which the pollutants in urban wastewater samples were removed by the M. oleifera coagulant, as mentioned by Nhut et al. [27]. The peptide polymer chain of the Moringa coagulant adsorbs pollutants that are present in the wastewater, such as organic matter [27,36]. In comparison with other natural coagulants, M. oleifera was able to remove $83.3 \%$ of COD, compared to $90.0 \%$ observed for Cicer aretinum and $80.7 \%$ for cactus [37], showing that it has good effectiveness.

Regarding $\mathrm{BOD}_{5}$, the variation in treatment was significant, but it was not dependent on all of the three factors that were studied $(p<0.05)$. Only the interaction between the "wastewater quality" and "variety used" factors had a significant effect on $\mathrm{BOD}_{5}$ content (Table 4). Before treatment, the BOD $_{5}$ value of the RUW slightly exceeded the limit set according to the standards, while that of the TUW complied with the standards (Table 3). Treatment with the coagulants of the three Moringa varieties resulted in the $\mathrm{BOD}_{5}$ of the RUW meeting the standards, while the TUW was left with lower $\mathrm{BOD}_{5}$ values. The optimum $\mathrm{BOD}_{5}$ removal efficiencies for the RUW (62.5\%) and TUW (86.6\%) were found with the Egyptian variety at the dose of $150 \mathrm{mg} \cdot \mathrm{L}^{-1}$. The higher the concentration of coagulant, the more the $\mathrm{BOD}_{5}$ decreased. These results corroborate the work of Adeniran et al., who noted that the COD of domestic wastewater decreased from 81.6 to $72 \mathrm{mg} \cdot \mathrm{L}^{-1}$ with Moringa seed treatment, while the $\mathrm{BOD}_{5}$ decreased from 96.5 to $80.2 \mathrm{mg} \cdot \mathrm{L}^{-1}$ [38]. The reduction in the $\mathrm{BOD}_{5}$ after treatment with the Moringa varieties shows that the treatment substantially reduced the amount of oxidizable material that was present in urban wastewater. Villaseñor-Basulto et al., reported that M. oleifara seeds continue to be used today in contemporary applications, mainly wastewater treatment. Indeed, the removal efficiency was very good for the tapioca starch effluents, with a $99 \%$ removal rate for both BOD and COD [10].

The $\mathrm{COD} / \mathrm{BOD}_{5}$ ratio provides information on the biodegradability of wastewater [39]. In our case, the $\mathrm{COD} / \mathrm{BOD}_{5}$ ratio of the RUW decreased mainly with the Mornag variety from 17.4 to its lowest value of 5.9 , which was observed with the $150 \mathrm{mg} \cdot \mathrm{L}^{-1}$ concentration. In contrast, the $\mathrm{COD} / \mathrm{BOD}_{5}$ ratio of the TUW increased with all tested Moringa varieties (Figure 3). The increase indicates that a significant fraction of the organic matter in the TUW was biologically removed, and therefore additional physicochemical treatment is recommended for the removal of the remaining non-biodegradable constituents in the TUW [40]. For both of the studied wastewater qualities, the COD/BOD 5 ratios that we obtained after the Moringa treatment were still greater than 3, thus showing that the biodegradability is low [41]. To remedy this, ultrafiltration following Moringa seed treatment is recommended because it can increase the COD removal rate from 40 to $99 \%$, according to Formentini-Schmitt et al. [42]. 


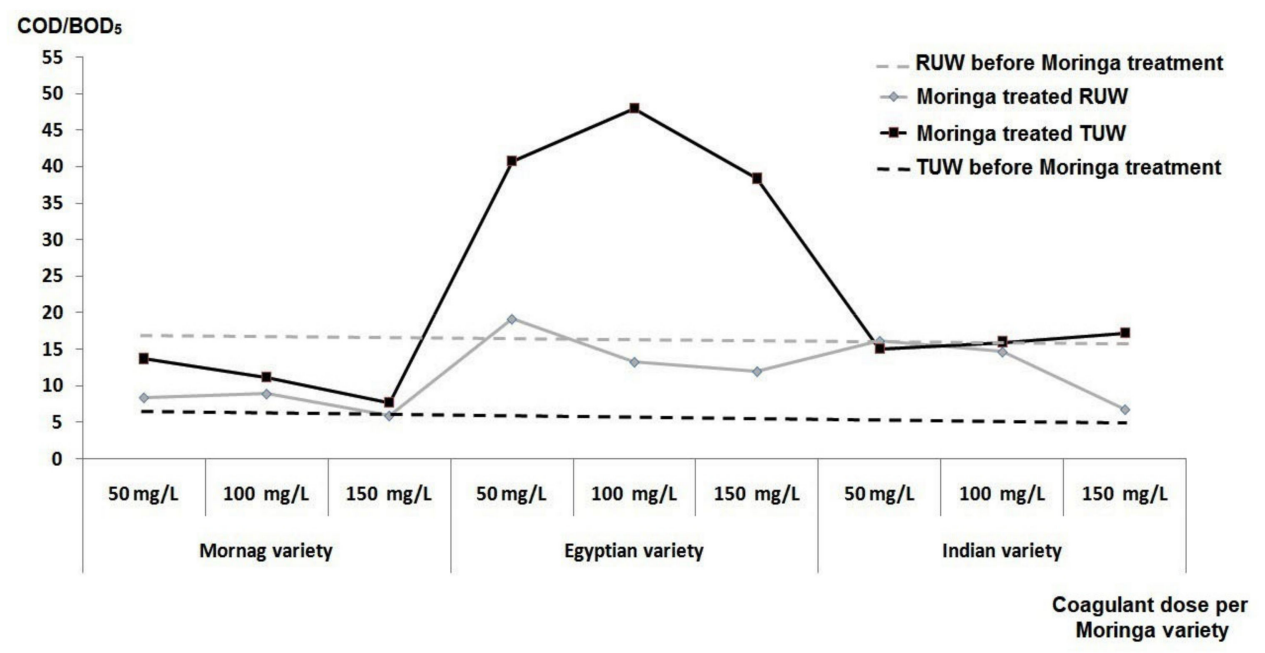

Figure 3. Treatment effect of application of Moringa oleifera variety on the $\mathrm{COD} / \mathrm{BOD}_{5}$ ratio.

\subsubsection{Influence of the Treatments on TSS Contents}

Statistical analyses revealed significant effects of the factors on TSS content $(p<0.05$; Table 4). The control RUW was very rich in TSS and treatments with all of the Moringa varieties reduced the content. However, the treatment was not sufficient for the wastewater to reach the standards for agricultural reuse. This was not the case for the TUW, which initially complied with these standards. The treatment with the coagulants served to further reduce the amount of TSS (Table 3). The Egyptian and Indian Moringa varieties were the most efficient at reducing TSS for the RUW at the dose of $150 \mathrm{mg} \cdot \mathrm{L}^{-1}(\mathrm{H}: 61.0 \%$ and $60.7 \%$, respectively). For the TUW, TSS removal efficiency was low: the optimum efficiency $(26 \%)$ was obtained with the Indian variety at $150 \mathrm{mg} \cdot \mathrm{L}^{-1}$. Better TSS removal efficiencies were recorded by researchers who have used other treatment processes. Hidayat et al., used a $150 \mathrm{mg} \cdot \mathrm{L}^{-1}$ dose of $M$. oleifera seeds in a primary sedimentation tank, followed by two stages of settling with natural filters (coconut fiber followed by sand) to remove organic matter in tapioca starch wastewater. The removal efficiency for TSS was 91\% [43]. Garde et al., used M. oleifera seed extract with distilled water to treat coffee industry effluents and recorded a TSS removal efficiency of 54\% [44]. Bhatia et al., removed a large amount of TSS (99.3\%) by mixing $M$. oleifera seed flour after lipid extraction with a liquid dispersion flocculant named NALCO 7751 [45]. These authors later used a factorial experimental design and response surface methodology to optimize their process and found that the optimum dose of M. oleifera was $3469 \mathrm{mg} \cdot \mathrm{L}^{-1}$ and that the optimum dose of NALCO 7751 was $6736 \mathrm{mg} \cdot \mathrm{L}^{-1}[46]$.

\subsubsection{Removal of Ion-Forming Salts}

For the removal of ion-forming salts $\left(\mathrm{Cl}^{-}, \mathrm{K}^{+}, \mathrm{Na}^{+}, \mathrm{HCO}_{3}{ }^{-}, \mathrm{SO}_{4}{ }^{2-}\right.$, and $\left.\mathrm{Ca}^{2+}\right)$, the variations in their content were found to be significant with the "wastewater quality" and "variety used" factors, and with the interaction between all of the tested factors $(p<0.05$; Table 4). The Egyptian variety at the dose of $150 \mathrm{mg} \cdot \mathrm{L}^{-1}$ reduced the $\mathrm{Cl}^{-}$and $\mathrm{SO}_{4}{ }^{2-}$ contents of the RUW with removal efficiencies of $24.5 \%$ and $54.93 \%$, respectively (Table 3 ). For the TUW, $\mathrm{Cl}^{-}$and $\mathrm{SO}_{4}{ }^{2-}$ decreased after treatment with all of the Moringa seed, although the optimum reductions $(45.4 \%$ and $71.6 \%$ ) were recorded for the Egyptian variety at $100-150 \mathrm{mg} \cdot \mathrm{L}^{-1}$ and $50 \mathrm{mg} \cdot \mathrm{L}^{-1}$, respectively. The cationic amino acids that comprise the coagulant attract and neutralize the negatively charged chloride ions. Chee et al., argued that the M. oleifera seed is a good coagulant for removing negatively charged ions due to its high porosity, its surface texture, and its high content of coagulant proteins (31.4\%) [47]. The M. oleifera protein seed is charged with cationic dimmers of about $6.5-13 \mathrm{kDa}$ that has an iso-electric point above 9.6. The interactions between the negatively charged ions and the M. oleifera seed therefore occurred through an ion adsorption mechanism [37]. The Egyptian 
variety was also efficient at reducing the concentrations of $\mathrm{Ca}^{2+}, \mathrm{Mg}^{2+}, \mathrm{K}^{+}$, and $\mathrm{Na}^{+}$ions for both types of urban wastewater. The Moringa seed coagulants therefore remove hardness from water through adsorption and inter-particle bridging [17]. Madhavan and Karpagam compared the Mg removal efficiency of the seeds of two natural coagulants, M. oleifera and Strychnos potatorum, testing them on tannery effluents. They observed that Strychnos potatorum (58.6\%) was more efficient at removing Mg than M. oleifera (42.9\%) [48].

\subsubsection{Influence of Treatment on TKN Concentration}

Regarding TKN contents, significant variation was detected according to the three studied factors. The variation was also dependent on their interaction $(p<0.05$; Table 4$)$. The results showed an increase in the TKN contents in both types of urban wastewater following their treatment with the three Moringa varieties (Table 3). This corroborates the work of Ndabigengesere and Narasiah, who found that TKN increased in domestic wastewater after being treated with $M$. oleifera seeds [49]. The TKN increase comes from the high contents of nutrients in the powdered Moringa seed [50]. To avoid the addition of TKN and other nutrients when using M. oleifera seed as a natural coagulant, the active protein needs to be purified. However, the process of nutrient removal needs to be further investigated [51]. The high amount of TKN in Moringa-treated urban wastewater means that it would be good for agricultural irrigation, however, because the use of such water would allow us to avoid using chemical nitrogen fertilizers that contribute to the pollution problems of groundwater [52]. Thus, using Moringa-treated urban wastewater would reduce production costs for the farmer.

\subsubsection{Metallic Trace Element (MTE) Removal}

Regarding MTE contents, the treatment of the RUW and TUW with the Egyptian variety at $150 \mathrm{mg} \cdot \mathrm{L}^{-1}$ led to a treated wastewater quality that was in accordance with the NT 106.03 standards, which relate to the reuse of treated wastewater for agricultural purposes (Table 3). The results revealed a significant variation in $\mathrm{Zn}$ content that was caused by all of the three factors and their interaction $(p<0.05$; Table 4$)$. Fe content varied significantly depending on the variety used and the coagulant concentration, and as well as their interaction $(p<0.05)$. In contrast, the $\mathrm{Ni}, \mathrm{Pb}$, and $\mathrm{Cd}$ contents were almost constant after treatment (Table 3). These results do not agree with the work of Shan et al., who showed that $\mathrm{Cd}$ was removed by up to $98 \%$ from wastewater and $\mathrm{Pb}$ by up to $78.1 \%$ [14]. Indeed, to ensure the proper removal of MTEs using plant material with a high oil content, such as M. oleifera seeds ( $34.8 \%)$, it would be necessary to extract the oil because it affects the coagulation activity and MTE removal [53]. Many authors stated that adsorption and charge neutralization are the result of the interaction mechanism between the M. oleifera proteins and MTEs [30,48,51,54]. The powdered M. oleifera seed has been considered to be a potential MTE-removing agent because of its oxygen and nitrogen-donating carboxylate and amino groups [54]. The MTE adsorption of Moringa is limited to surface adsorption because M. oleifera is a cationic polyelectrolyte with a short chain and low molecular weight. The adsorption occurs because positive metal ions form a bridge between the anionic polyelectrolyte and negatively charged protein functional groups on the surface of the colloidal particle. The structure of the polyelectrolyte coagulant consists of repeating units with a small molecular weight that form molecules of a colloidal size which carry electrical charges or ionizable groups, providing a bonding surface for the flocs $[55,56]$. In the coagulation process, MTE ions react with proteins and destroy them in wastewater. MTE adsorption occurs due to the seed's high protein content. By increasing the amount of positive charges in the solution, a clearing mechanism probably dominated in the solution, and the MTE ions therefore moved in colloid-polymer flocs that then settled [54].

\subsection{Clustering of Moringa oleifera Varieties}

A PCA, based on the removal efficiencies for the parameters that we studied here, was used to analyze the similarities between and the variational properties of the treatment 
efficiency. For the RUW, the first two PCAs represented $66.7 \%$ of the total variation. PCA1 (39.9\% of total variation) was positively correlated with TKN and K contents. PCA2 (27.3\% of total variation) was positively correlated with $\mathrm{SO}_{4}$ and $\mathrm{Cl}$ contents and was negatively correlated with $\mathrm{HCO}_{3}$. The first two PCAs were used to structure the RUW samples into three groups:

- The first group was represented by the negative aspects of PCA1 and PCA2. It constituted the RUW that had been treated with the Mornag variety at 50, 100, and $150 \mathrm{mg} \cdot \mathrm{L}^{-1}$. This treatment exhibited the lowest EC removal efficiencies $(2.2-3.3 \%)$ and the highest amount of COD removal (75.9-86.2\%);

- The second, with the positive aspects of PCA1, included the RUW that had been treated with the Egyptian variety at different doses. These treatments corresponded with the best treatment of $\mathrm{BOD}_{5}(56.4-62.5 \%)$, EC (20.2-22.0\%), TSS $(21.7-69.6 \%)$, $\mathrm{Ca}(33.3-46.7 \%), \mathrm{Na}(4.8-8.3 \%), \mathrm{Cl}(25.0 \%), \mathrm{SO}_{4}(46.9-54.9 \%), \mathrm{Cd}(100 \%)$, and $\mathrm{Fe}$ (30.5-65.2\%);

- The third group, with the negative aspects of PCA1 and the positive aspects of PCA2, included the RUW that had been treated with the Indian variety at different added concentrations. It was characterized by the lowest removal efficiencies for $\mathrm{BOD}_{5}$ (40.6-46.8\%), and the highest for K (23.4-24.6\%), Pb (2.2-24.5\%), Zn (0.6-22.7\%), and $\mathrm{Ni}(2.2-24.4 \%)$.

The TUW samples could be structured into four groups based on the PCA results (69.0\% of total variation):

- The first group had the positive aspects of PCA1 and PCA2. It contained the TUW that had been treated with the Mornag variety at different added concentrations. These treatments resulted in the highest amount of COD removal (75.9-86.2\%), and a chloride removal efficiency of $18.2 \%$ and the lowest removal efficiency for EC (3.9-5.2\%);

- The second group, with the positive aspects of PCA1 and the negative aspects of PCA2, was formed by the TUW that was treated with the Egyptian variety at doses of 50 and $100 \mathrm{mg} \cdot \mathrm{L}^{-1}$. These treatments resulted in the highest removal efficiency for $\mathrm{SO}_{4}(70.0-71.6 \%)$;

- The third group, with the negative aspects of PCA1 and PCA2, included the TUW that was treated with the Egyptian variety at $150 \mathrm{mg} \cdot \mathrm{L}^{-1}$, which had the highest removal efficiency for $\mathrm{BOD}_{5}(86.6 \%), \mathrm{EC}(29.7 \%), \mathrm{Cl}(45.5 \%), \mathrm{Mg}(18.2 \%), \mathrm{Na}(23.7 \%)$, and Cd (100\%);

- The fourth group, with the negative aspects of PCA1 and the positive aspects of PCA2, was represented by the TUW that had been treated with the Indian variety for all added concentrations. These treatments displayed the highest Fe removal efficiency (45.2-58.1\%).

PCA1 and PCA2 show that the Egyptian variety, has presented satisfactory results in treating both of the urban wastewater types at the dose of $150 \mathrm{mg} \cdot \mathrm{L}^{-1}$. It can therefore be used as an alternative for the chemical coagulants that are commonly used in the wastewater treatment plants in Tunisia [15] because of its low cost, abundance, and its environmentally friendliness, and because it does not leave toxic residues [48]. The efficiency and simplicity of this treatment method, in addition to the fertilizing power of the Moringa-treated wastewater, would encourage farmers to use it to improve the quality of the TUW that is used for irrigation.

\section{Conclusions}

The treatment effect of the seeds of three $M$. oleifera varieties was evaluated using the concentrations of $0,50,100$, and $150 \mathrm{mg} \cdot \mathrm{L}^{-1}$ on raw (RUW) and treated urban wastewater (TUW). The treatment was efficient at reducing the contaminants that are present in both types of urban wastewater. Wastewater quality had a significant effect on the variation $(66.6 \%)$ of the studied water treatments. The M. oleifera variety significantly influenced the treatment outcome $(77.7 \%)$, and the type of treatment applied also had a significant 
effect $(55.5 \%)$. The Egyptian variety presented satisfactory results when treating both of the urban wastewater types at the dose of $150 \mathrm{mg} \cdot \mathrm{L}^{-1}$ because it resulted in the best reduction of $\mathrm{EC}$, TSS, $\mathrm{BOD}_{5}, \mathrm{Cl}, \mathrm{SO}_{4}, \mathrm{Ca}, \mathrm{Na}, \mathrm{Cd}$, and $\mathrm{Fe}$ in the RUW and $\mathrm{BOD}_{5}, \mathrm{EC}, \mathrm{Na}$, $\mathrm{Mg}, \mathrm{Cl}$ and $\mathrm{Cd}$ in the TUW. The high TKN amount in Moringa-treated urban wastewater means that it would be suited for use in agricultural irrigation because it means farmers can avoid using chemical nitrogen fertilizers. Thus, urban wastewater treated with the $M$. oleifera coagulants can be used in irrigation, without inconvenience to crops, soil, animals, and human consumers. In addition, the Egyptian Moringa variety is a cost-effective and environmentally friendly adsorbent that can be used as a replacement for other expensive treatment technologies.

To the authors' knowledge, this is one of the first studies to have investigated the treatment of urban wastewater using M. oleifera in northern Africa. Tunisia, as well as many other MENA countries, suffers from severe water and energy shortages. Developing alternative, inexpensive treatment methods is therefore of great importance. Similarly, Tunisia shares common climate characteristics and socioeconomic conditions with many other MENA countries, with resulting similarities in wastewater properties. Thus, the results of this study can potentially be important and applicable for many other countries in the MENA region.

Author Contributions: Conceptualization, N.M. and N.S.; methodology, S.D. and M.B.; formal analysis, N.M.; validation, M.H. and N.S.; investigation, N.M. and F.G.; resources, F.G.; writingoriginal draft preparation, N.M.; writing-review and editing, R.B.; visualization, S.D.; supervision, M.H.; funding acquisition, R.B. All authors have read and agreed to the published version of the manuscript.

Funding: The APC was funded by the European Union Horizon 2020 program FASTER project, grant agreement No [810812] and the MECW (Middle East in the Contemporary World) project at the Centre for Advanced Middle Eastern Studies, Lund University.

Institutional Review Board Statement: Not applicable.

Informed Consent Statement: Not applicable.

Data Availability Statement: Not applicable.

Acknowledgments: The authors thank Mokhtar Mahdouani from "Agriculture Générale" company in Kairouan and Ahmed Elmansi from "The tree of life Moringa oleifera" company in Ben Arous for supplying Moringa oleifera seed varieties.

Conflicts of Interest: The authors declare no conflict of interest.

\section{References}

1. United Nations World Water Assessment Programme. The United Nations World Water Development Report: Water and Jobs; UNESCO: Paris, France, 2016.

2. United Nations World Water Assessment Programme. The United Nations World Water Development Report: Nature-Based Solutions for Water; UNESCO: Paris, France, 2018.

3. United Nations World Water Assessment Programme. The United Nations World Water Development Report: Wastewater: The Untapped Resource; UNESCO: Paris, France, 2017.

4. Jobin, L.; Namour, P. Bioremediation in Water Environment: Controlled Electro-Stimulation of Organic Matter Self-Purification in Aquatic Environments. Adv. Microbiol. 2017, 7, 813-852. [CrossRef]

5. Ince, M.; Kaplan Ince, O. Heavy Metal Removal Techniques Using Response Surface Methodology: Water/Wastewater Treatment. In Biochemical Toxicology_Heavy Metals and Nanomaterials; Ince, M., Kaplan Ince, O., Ondrasek, G., Eds.; IntechOpen: London, UK, 2019. [CrossRef]

6. Mamais, D.; Noutsopoulos, C.; Dimopoulou, A.; Stasinakis, A.; Lekkas, T.D. Wastewater treatment process impact on energy savings and greenhouse gas emissions. Water Sci. Technol. 2015, 71, 303-308. [CrossRef] [PubMed]

7. Rajasulochana, P.; Preethy, V. Comparison on efficiency of various techniques in treatment of waste and sewage water-A comprehensive review. Resour. Efficient Technol. 2016, 2, 175-184. [CrossRef]

8. Hamdi, M. Lessons from rhizosphere and gastrointestinal ecosystems for inventive design of sustainable wastes recycling bioreactors. Biochem. Eng. J. 2016, 105, 62-70. [CrossRef] 
9. Ahluwalia, S.S.; Goyal, D. Microbial and plant derived biomass for removal of heavy metals from wastewater. Bioresour. Technol. 2007, 98, 2243-2257. [CrossRef] [PubMed]

10. Villaseñor-Basulto, D.L.; Astudillo-Sánchez, P.D.; del Real-Olvera, J.; Bandala, E.R. Wastewater treatment using Moringa oleifera Lam seeds: A review. J. Water Process Eng. 2018, 23, 151-164. [CrossRef]

11. Vogelmann, E.S.; Awe, G.O.; Prevedello, J. Selection of plant species used in wastewater treatment. In Wastewater Treatment and Reuse for Metropolitan Regions and Small Cities in Developing Countries; de Lima, E.S., Ed.; Cuvillier: Recife, Brazil, 2016 ; pp. 9-18.

12. Marzougui, N.; Hammami, A.; Guasmi, F.; Rejeb, S. Effects of temperature and treated urban wastewater on seed germination and seedling growth in different populations of Moringa oleifera (Lam.). Indian J. Exp. Biol. 2021, 59, 349-356.

13. Goja, A.M.; Osman, M.S. Preliminary study on efficacy of leaves, seeds and bark extracts of Moringa oleifera in reducing bacterial load in water. Int. J. Adv. Res. 2013, 1, 124-130.

14. Shan, T.C.; Al Matar, M.; Makky, E.A.; Ali, E.N. The use of Moringa oleifera seed as a natural coagulant for wastewater treatment and heavy metals removal. Appl. Water Sci. 2017, 7, 1369-1376. [CrossRef]

15. ONAS (National Sanitation Utility, Tunisia). Annual Operating Report for Wastewater Treatment Plants; Ministry of the Environment and Sustainable Development: Tunis, Tunisia, 2019. (In French)

16. Rajeswari, M.; Agrawal, P.; Pavithra, S.; Priya Sandhya, G.R.; Pavithra, G.M. Continuous biosorption of cadmium by Moringa oleifera in a packed column. Biotechnol. Bioprocess Eng. 2013, 18, 321-325. [CrossRef]

17. Mangale Sapana, M.; Chonde, S.G.; Raut, P.D. Use of Moringa oleifera (Drumstick) seed as natural absorbent and an antimicrobial agent for ground water treatment. Res. J. Recent Sci. 2012, 1, 31-40.

18. INNORPI (National Institute for Standardization and Industrial Property, Tunisia). Environmental Protection-Effluent Discharge into the Water Environment; Tunisian Standard NT 106.02; Ministry of Industry, Energy and Mines: Tunis, Tunisia, 1989. (In French)

19. INNORPI (National Institute for Standardization and Industrial Property, Tunisia). Environmental Protection-Use of Treated Wastewater for Agricultural Purposes_Physico-Chemical and Biological Specifications; Tunisian Standard NT 106.03; Ministry of Industry, Energy and Mines: Tunis, Tunisia, 1989. (In French)

20. Baird, R.B.; Eaten, A.D.; Rice, E.W. Standard Methods for the Examination of Water and Wastewater, 23rd ed.; American Public Health Association: Washington, DC, USA, 2017; pp. 587-589.

21. Rodier, J.; Legube, B.; Merlet, N. L'analyse de L'eau: Contrôle et Interprétation, 10th ed.; Dunod: Paris, France, 2016; pp. 69-73.

22. Belcher, R.; Macdonald, A.M.G.; Parry, E. On Mohr's method for the determination of chlorides. Anal. Chim. Acta 1957, 16, 524-529. [CrossRef]

23. Rodier, J.; Legube, B.; Merlet, N. L'analyse de L'eau: Contrôle et Interprétation, 10th ed.; Dunod: Paris, France, 2016 ; pp. 162-185.

24. Ringbom, A.; Pensar, G.; Wänninen, E. A complexometric titration method for determining calcium in the presence of magnesium. Anal. Chim. Acta 1958, 19, 525-531. [CrossRef]

25. Rodier, J.; Legube, B.; Merlet, N. L'analyse de L'eau: Contrôle et Interprétation, 9th ed.; Dunod: Paris, France, 2009 ; pp. 995-996.

26. Sleimi, N.; Kouki, R.; Hadj Ammar, M.; Ferreira, R.; Perez-Clemente, R. Barium effect on germination, plant growth, and antioxidant enzymes in Cucumis sativus L. plants. Food Sci. Nutr. 2021, 9, 2086-2094. [CrossRef] [PubMed]

27. Nhut, H.T.; Hung, N.T.Q.; Lap, B.Q.; Han, L.T.N.; Tri, T.Q.; Bang, N.H.K.; Hiep, N.T.; Ky, N.M. Use of Moringa oleifera seeds powder as bio-coagulants for the surface water treatment. Int. J. Environ. Sci. Technol. 2020, 18, 2173-2180. [CrossRef]

28. Sahu, O.P.; Chaudhari, P.K. Review on chemical treatment of industrial waste water. J. Appl. Sci. Environ. Manag. 2013, 17, 241-257. [CrossRef]

29. Hendrawati; Yuliastri, I.R.; Nurhasni; Rohaeti, E.; Effendi, H.; Darusman, L.K. The use of Moringa oleifera seed powder as coagulant to improve the quality of wastewater and ground water. In IOP Conference Series: Earth and Environmental Science; In Proceedings of the Workshop and International Seminar on Science of Complex Natural Systems, Bogor, Indonesia, 9-10 October 2015; IOP Publishing: Philadelphia, PA, USA, 2016; Volume 31, p. 01203. [CrossRef]

30. Naceradska, N.; Pivokonska, L.; Pivokonsky, M. On the importance of pH value in coagulation. J. Water Supply Res. T. 2019, 68, 222-230. [CrossRef]

31. Amagloh, F.K.; Benang, A. Effectiveness of Moringa oleifera seed as coagulant for water purification. Afr. J. Agric. Res. 2009, 4, 119-123.

32. Abdulsalam, S.; Gital, A.A.; Misau, I.M.; Suleiman, M.S. Water clarification using Moringa oleifera seed coagulant: Maiduguri raw water as a case study. J. Food Agric. Environ. 2007, 5, 302-306. [CrossRef]

33. Belghyti, D.; El Guamri, Y.; Ztit, G.; Ouahidi, M.L.; Joti, B.; Harchrass, A.; Amghar, H.; Bouchouata, O.; El Kharrim, K.; Bounouira, H. Caractérisation physico-chimique des eaux usées d'abattoir en vue de la mise en œuvre d'un traitement adéquat: Cas de Kénitra au Maroc. Afr. Sci. Rev. Int. Sci. Technol. 2009, 5, 199-216. [CrossRef]

34. Adewole, S.T.; Kuku, A.; Okoya, A. Efficacy of a natural coagulant protein from Moringa oleifera (Lam) seeds in treatment of Opa reservoir water, Ile-Ife, Nigeria. Heliyon 2020, 6, e03335. [CrossRef]

35. Nonfodji, O.M.; Fatombi, J.K.; Ahoyo, T.A.; Osseni, S.A.; Aminou, T. Performance of Moringa oleifera seeds protein and Moringa oleifera seeds protein-polyaluminum chloride composite coagulant in removing organic matter and antibiotic resistant bacteria from hospital wastewater. J. Water Process Eng. 2020, 33, 101103. [CrossRef]

36. Teh, C.Y.; Budiman, P.M.; Shak, K.P.Y.; Wu, T.Y. Recent advancement of coagulation flocculation and its application in wastewater treatment. Ind. Eng. Chem. Res. 2016, 55, 4363-4389. [CrossRef] 
37. Kumar, V.; Othman, N.; Asharuddin, S. Applications of Natural Coagulants to Treat Wastewater-A Review. MATEC Web Conf. 2017, 103, 06016. [CrossRef]

38. Adeniran, K.A.; Akpenpuun, T.D.; Akinyemi, B.A.; Wasiu, R.A. Effectiveness of Moringa oleifera seed as a coagulant in domestic wastewater treatment. African J. Sci. Technol. Innov. Dev. 2017, 9, 323-328. [CrossRef]

39. Bratby, J. Coagulation and Flocculation in Water and Wastewater Treatment, 3rd ed.; IWA Publishing: London, UK, 2016; pp. 152-158.

40. Vega Andrade, P.; Ferreira Palanca, C.; Alcion'eia Carvalho de Oliveira, M.; Ito, C.Y.K.; Gonçalves dos Reis, A. Use of Moringa oleifera seed as a natural coagulant in domestic wastewater tertiary treatment: Physicochemical, cytotoxicity and bacterial load evaluation. J. Water Process Eng. 2021, 40, 101859. [CrossRef]

41. Aissaoui, M.; Benhamza, M.; Guettaf, M. Caractéristiques hydro-chimiques des eaux de l'oued Seybouse-Cas de la région de Guelma (Nord-est Algérien) (Hydro-chemical characteristics of the Seybouse river - Case study of the Guelma region (Northeast of Algeria)). Rev. Sci. Technol. Synthèse 2017, 35, 178-186.

42. Formentini-Schmitt, D.M.; Alves, Á.C.D.; Veit, M.T.; Bergamasco, R.; Vieira, A.M.S.; Fagundes-Klen, M.R. Ultrafiltration combined with Coagulation/Flocculation/Sedimentation using Moringa oleifera as coagulant to treat dairy industry wastewater. Water Air Soil Pollut. 2013, 224, 1682. [CrossRef]

43. Hidayat, N.; Suhartini, S.; Rosalina, E. Influence of powdered Moringa oleifera seeds and natural filter media on the characteristics of tapioca starch wastewater. Int. J. Recycl. Org. Waste Agric. 2013, 2, 12. [CrossRef]

44. Garde, W.K.; Buchberger, S.G.; Wendell, D.; Kupferle, M.J. Application of Moringa oleifera seed extract to treat coffee fermentation wastewater. J. Hazard. Mater. 2017, 329, 102-109. [CrossRef] [PubMed]

45. Bhatia, S.; Othman, Z.; Ahmad, A.L. Pretreatment of palm oil mill effluent (POME) using Moringa oleifera seeds as natural coagulant. J. Hazard. Mater. 2007, 145, 120-126. [CrossRef]

46. Bhatia, S.; Othman, Z.; Ahmad, A.L. Coagulation-flocculation process for POME treatment using Moringa oleifera seeds extract: Optimization studies. Optim. Stud. Chem. Eng. J. 2007, 133, 205-212. [CrossRef]

47. Chee, V.L.; Chong, C.H.; Choo, C.M.; Chong, T.S.Y. Combined natural and chemical coagulants to remove fluoride from wastewater. In IOP Conference Series: Materials Science and Engineering; In Proceedings of the 26th Regional Symposium on Chemical Engineering (RSCE 2019), Kuala Lumpur, Malaysia, 30-31 October 2019; IOP Publishing: Philadelphia, PA, USA, 2020. [CrossRef]

48. Madhavan, S.A.K.S.; Karpagam, S. Natural coagulants: An easy way to remove heavy metals from tannery effluents. J. Ind. Pollut.Control 2019, 35, 2266-2270.

49. Ndabigengesere, A.; Narasiah, K.S. Use of Moringa oleifera seeds as a primary coagulant in wastewater treatment. Environ. Technol. 1998, 19, 789-800. [CrossRef]

50. Mendieta-Araica, B.; Spörndly, E.; Reyes-Sánchez, N.; Salmerón-Miranda, F.; Halling, M. Biomass production and chemical composition of Moringa oleifera under different planting densities and levels of nitrogen fertilization. Agroforest. Syst. 2012, 87, 81-92. [CrossRef]

51. Slinning Aarø, S. A review of selected natural coagulants in water and wastewater treatment. Master's Thesis, Norwegian University of Life Sciences, Ås, Norway, June 2020.

52. Byrnes, B.H. Environmental effects of N fertilizer use-An overview. Fertil. Res. 1990, 26, 209-215. [CrossRef]

53. Eman, N.A.; Tan, C.S.; Makky, E.A. Impact of Moringa oleifera cake residue application on wastewater treatment: A case study. J. Water Resource Prot. 2014, 6, 677-687. [CrossRef]

54. Mehdinejad, M.H.; Bina, B. Application of Moringa oleifera coagulant protein as natural coagulant aid with alum for removal of heavy metals from raw water. Desalin. Water Treat. 2018, 116, 187-194. [CrossRef]

55. Ndabigengesere, A.; Narasiah, K.S.; Talbot, B.G. Active agents and mechanism of coagulation of turbid waters using Moringa oleifera. Water Res. 1995, 29, 703-710. [CrossRef]

56. Ravikumar, K.; Sheeja, A.K. Heavy metal removal from water using Moringa oleifera seed coagulant and double filtration. Int. J. Sci. Eng. Res. 2013, 4, 10-13. 